\title{
Enterprise Economic Management Innovation Strategy Research under the New Situation
}

\author{
Zhou Jian \\ Jiangxi vocational college of finance and economics, 332000
}

\begin{abstract}
Keywords: New situation; Open; Enterprise economic management; Current situation; Innovation strategy
\end{abstract}

\begin{abstract}
With the increasing of openness, the competition between enterprises in our country is increasingly fierce. Innovation is the source of enterprises' competitive advantage in the fierce market competition. For this reason, under the background of the current new period, explore enterprise economic management innovation strategy has extremely important practical significance. This article analyzes the present situation of the enterprise's economic management under the new situation, and analyzes enterprise innovation strategy on the basis of it. It is believed that this paper will provide certain reference and reference to our country’s enterprises.
\end{abstract}

\section{Introduction}

Under the background of gradually in-depth reform and opening up in our country, our country's economy is facing a more broad development space, and enterprises have better development opportunity in good economic environment, but in the process, rapid development enterprises in our country present a more intense competition. In such fierce market competition, enterprises must continuously improve their economic benefits to survive and develop, and this depends on innovation as the foundation. According to such situation, this article studies economic management innovation strategy under the current new situation.

\section{The Connotation of the Current Enterprise Management Innovation}

Generally speaking, the implementation of management innovation mainly refers that to some extent innovate many aspects of enterprises' inherent operation and management, traditional thoughts, strategic management, and management, such as management mode. In the meantime, attach great importance to the ideological and political work of all employees in the enterprise. Based on person's point of view----active factors smoothly implement the corresponding control and promote the innovation in enterprise's economic management work. Enterprise management innovation has a relatively complex process. From this perspective, the process of enterprise implementing enterprise management innovation must firmly grasp the key factors; avoid the waste of manpower, material resources, and financial resources effectively. Through management innovation, enterprises can be injected new vigor and source so as to achieve rational allocation of production factors and effectively cope with risks, which is helpful for enterprises to gain maximum benefit. It plays an effective role in promoting sustainable development for the enterprise. Enterprise innovation is to get new, further understanding and grasp of the enterprise and its covering different aspects' "essence". The human understanding of the nature of enterprise is gradually deepened. On the one hand, the understanding of the objective existence of the "enterprise" needs to be deepened; on the other hand, the "enterprise" itself is changing with the development of the society. It was believed that the enterprise is to produce products or provide services. Now we don't think enterprise primary produce products, but "manufacture" thought; Enterprise not only provides services, but provides new ideas. It was generally believed that the goals of enterprise are to maximize the profits or maximize shareholders' equity. Now the customer is the foundation of the enterprise, and enterprise survival element. Everything the enterprise owns is given by the customer. In order to supply the customer's demand, the society offers wealth of resources for the enterprises to exploit, and make enterprises 
shoulder the responsibility. Only benefit for customers, and have mutual interests with customers can enterprises provide customers with "perceived value", so as to make the enterprise obtain ideal, even supernormal profits.

\section{Enterprise Economic Management Innovation Strategy under the New Situation}

First is positive innovation of enterprise brand management. Enterprise brand innovation means reform and innovation of the traditional human low levels production. Overhaul the traditional backward production way, on the basis of which, create a new enterprise exclusive brand. By means of it, the enterprise's reputation and popularity improve, so that enterprises can increase the added value of products intangibly. Then foothold is firmly in the middle of the whole market. This will have to take the lead in establishing and perfecting the three-dimensional enterprise marketing network, no doubt, whether to get huge success; enterprise must be based on powerful r\&d ability and good brand influence. Only brands turn into money, in this respect, the most persuasive way is Microsoft in the United States. In the 1970 s, Bill Gates only started with just a few thousand dollars, but by 1998, he hit a record of $\$ 100$ billion in assets, that is to say, 20 years his assets increased tens of millions of times. It's all brand innovation. Enterprise owned by excellent after-sales service, good corporate reputation and lending products tends to attract more consumers to become loyal user community. And in this process, enterprises should also pay great attention to the association with other vendors and cooperation. The enterprise holds two directions of the industrial chain, upstream and downstream, effectively integrates network marketing, physical distribution manufacturers, operators and manufacturers, etc., and makes full use of enterprise resources provided by partners, forms its own marketing network, so as to provide more high quality service to customers, and make the win-win situation in enterprises' whole industry chain.

Second is positive innovation enterprise management consciousness. In the process of implementation of enterprise management innovation in our country, all the enterprise internal staff from top to bottom should update management innovation, gradually transfer traditional pursuit profit to form self-sustaining management thought and a sense of responsibility. Introduce strategic consciousness, crisis management consciousness into the enterprise, and the corresponding management works in the management of the enterprise goals and management policy formulation process, so the enterprise implements according to the overall situation and gradually forms global concepts and scientific management in internal enterprise. Based on the social environment of current profit maximization, new concept of enterprise innovation is set according to diversified business objectives, do greater level of development to enterprise thinking. Actively explore better management goal seems particularly important. Under the background of current knowledge economy era, an important strategic means for the survival and development of enterprises in the fierce competition is to develop a good cooperation and competition enterprise strategy. Constant and effective strengthening of enterprise management enhances personnel's quality. Often nonofficial and specialized entrepreneurs are much-needed talent type in the development process of future business enterprise. With making all kinds of examination system and setting up various training courses, the enterprise staff management ability is increased continuously, the enterprise staff sense of responsibility is effective reinforced to avoid larger errors in enterprise management work.

Third is by means of the implementation of corresponding enterprise product market research, to make the products management innovation of the enterprise. Enterprises, under the current market economy system, should attach great importance to the changes and the changing market, and put enough energy in researching market. The market essentially belongs to the orientation of enterprise development, and the development direction of enterprises is under the influence of market demand, market demand will benefit the development of enterprises production. Under the background of current increasing market competition, a kind of important tactics companies adopting is price war. This tactic especially flourishes under the market economy system. For this reason, enterprise innovation in product price is an inevitable trend of enterprise development. Based on the corresponding full market research, further develop new products in line with market demand, and 
continuously inject vitality of enterprises. Specifically, you can through the following two aspects: on the one hand, formulate corresponding enterprise product standards worldwide, appropriately adjust their own product standards so as to adapt to the requirements of current international standard, and truly let enterprise products implement according to standardized procedures; On the other hand, if the enterprise wants to gain dominant position in global competition, it must do efforts to improve the enterprise itself, and with the help of long-term efforts, the standards are used to carry on redesign, and in the process of trying to gradually become the standard of international standard, expand the scope of influences of these standards to the utmost. By means of the implementation of market segmentation, which more pay attention to the symbolic products for consumers, so as to seize the consumption characteristics of target consumers. Based on fashion design and good quality of product support, at the same time implement product sales, and achieve the purpose of marketing innovation and elite enterprise culture idea. In addition, it should make full use of enterprise product brand advantage, shortens maximally the product life cycle, and actively promotes upgrading of products in order to obtain higher profits.

Fourth is active innovation enterprise financial management. On financial management of enterprises, a comprehensive budget management for enterprises is innovated. Enterprise financial management innovation's concrete implementation should from the following three points: the first is to predict the future possible risk by using the scientific method, and then do reasonable allocation of resources; the second, budget work must let the staff to participate actively. To ensure timely feedback information effectively, only by making the enterprise and the staff are involved can realize reasonable allocate resources; The third point is to set the core of enterprise economic management innovation as enterprise financial management comprehensive distribution and control of all financial and non-financial resources, such as a certain department within the enterprise must have detailed plan of control and operating income, cash flow, capital flow, operating cost, capital requirements, etc.

Fifth is positive innovation enterprise's metrological management. The enterprise's measuring data management can provide a solid basis on enterprises implementing modern decision-making and management. Measurement data exists in enterprise planning and research, product quality control, product design, production and marketing, such as strengthening the management of these data, which can help to improve scientific decision-making and management of the enterprises. And in this process, through effective strengthening of management measurement data, the enterprise loss can be decreased, and the comprehensive economic benefits of enterprises are improved for enterprises effective promotion on sustainable development. Generally speaking, there is a close relationship between enterprise metrological management and enterprise operation and management. Quite a number of companies take measure management as a basic work to improve enterprise management implement. In many cases, with the measurement of enterprise management, combined with perfect corresponding measurement detection means, finally achieve the goal of enterprise resource configuration optimization, which can lead to enterprise resource consumption and enhance enterprise's economic efficiency. By innovative use of measurement acceptance check draft settlement ore transportation, Wuhan iron organization directly do actual traffic voyage. Ore loading capacity has nothing to do with the attitude of the changes. Consciously monitor port shipment quantity in the process of loading ore, reduce insufficient transmission loading capacity, and lead to port rate of Wuhan iron ore resources. According to the relative statistic data of the first 11 months of 2012, 19293992 tons ore were accepted out of among the measurement of a total of 6150 ships. By comparing the scheme and data of prior implementation, only the transport ore cost is to avoid economic losses of more than three million Yuan.

\section{Enterprise Management Innovation Cases and Review}

Enterprises implementing enterprise management innovation in our country has the representative Shanghai General Motors. Because the vast majority of auto makers in China adopt a way of manufacture: a factory, a pipeline, a platform, a model, while GM uses flexible management, which 
can produce four different models on one platform in one line, which belongs to the innovation of domestic automobile enterprises. Strict and standard procurement systems, scientific and strict logistics distribution system, and highly flexible lean production system, market as the guidance, customer as the center customer relationship management constitute the support system of flexible production management. Flexible production can bring money and time to consumers and manufacturers. Shanghai GM's Buick GS and Buick Sail are very good proofs, which made Shanghai GM the most flexible manufacturer worldwide, and has formed a classic example of enterprise flexible management.

Shanghai GM flexible production management is not just for the production line of flexible manufacturing technology, but rather a customer-centered flexible and lean concept service quality from procurement, logistics, engineering, manufacturing to sales. Over the years, it has become Shanghai General Enterprise's core value, and goes deep into the enterprise operation and management of every link.

\section{Conclusion}

This article analyzes the current enterprise management innovation measures under new situation. We summarize the connotation of management innovation, and put forward the significance of management innovation implementation. Based on the basis of analysis of innovation measures, we hope to provide reference for the development of enterprise management innovation in the new period.

\section{References}

[1] Liu Bingmei. Analyze the innovation way of enterprise economic management under the new situation[J]. Chinese Investment: 2013 (S1) : 231-232

[2] Li Jun. Economic management innovation strategy in the new period[J]. Chinese and Foreign Entrepreneurs. 2013 (8): 52-53

[3] Zhang Ying, Ren Guihong. On innovation and practice of enterprise economic management under the new situation[J]. Journal of China Commerce: 2013 (02) : 46-47

[4] Zhuang Wensheng. How to realize innovation in economic management under the new situation[J]. Journal of Financial Times: 2012 (9) : 76-77 